\title{
Excessive Extracellular ATP Desensitizes P2Y2 and P2X4 ATP Receptors Provoking Surfactant Impairment Ending in Ventilation-Induced Lung Injury
}

\author{
Djo Hasan ${ }^{1,2, *}$, Joshua Satalin ${ }^{3}$, Philip van der Zee ${ }^{4}$ (i), Michaela Kollisch-Singule ${ }^{3}$, \\ Paul Blankman ${ }^{5}$, Atsuko Shono ${ }^{6}$ (i), Peter Somhorst ${ }^{4}$, Corstiaan den Uil ${ }^{4,7}$, Han Meeder ${ }^{1,4}$, \\ Toru Kotani ${ }^{8}$ (1) and Gary F. Nieman ${ }^{3}$ \\ 1 Mobile Intensive Care Unit Zuid-West Nederland, 3062 NW Rotterdam, The Netherlands; jmeeder@chello.nl \\ 2 Department of Surgery, Erasmus MC, Erasmus Universiteit Rotterdam, 3015 CE Rotterdam, The Netherlands \\ 3 Department of Surgery, Upstate Medical University, Syracuse, NY 13210, USA; satalinj@upstate.edu (J.S.); \\ kolliscm@upstate.edu (M.K.-S.); niemang@upstate.edu (G.F.N.) \\ 4 Adult Intensive Care Unit, Erasmus MC, Erasmus Universiteit Rotterdam, 3015 CE Rotterdam, \\ The Netherlands; p.vanderzee@erasmusmc.nl (P.v.d.Z.); p.somhorst@erasmusmc.nl (P.S.); \\ c.denuil@erasmusmc.nl (C.d.U.) \\ 5 Department of Anesthesiology, Universitair Medisch Centrum Utrecht, 3584 CX Utrecht, The Netherlands; \\ p.blankman@umcutrecht.nl \\ 6 Department of Anesthesiology, Shimane University, Izumo, Shimane Prefecture 693-0021, Japan; \\ atsukos@med.shimane-u.ac.jp \\ 7 Department of Cardiology, Erasmus MC, Erasmus Universiteit Rotterdam, 3062 PA Rotterdam, \\ The Netherlands \\ 8 Department of Anesthesiology and Critical Care Medicine, Showa University, School of Medicine, \\ Tokyo 142-8666, Japan; trkotani@med.showa-u.ac.jp \\ * Correspondence: djohasan@gmail.com; Tel.: +31-622804415
}

Received: 5 March 2018; Accepted: 10 April 2018; Published: 13 April 2018

\begin{abstract}
Stretching the alveolar epithelial type I (AT I) cells controls the intercellular signaling for the exocytosis of surfactant by the AT II cells through the extracellular release of adenosine triphosphate (ATP) (purinergic signaling). Extracellular ATP is cleared by extracellular ATPases, maintaining its homeostasis and enabling the lung to adapt the exocytosis of surfactant to the demand. Vigorous deformation of the AT I cells by high mechanical power ventilation causes a massive release of extracellular ATP beyond the clearance capacity of the extracellular ATPases. When extracellular ATP reaches levels $>100 \mu \mathrm{M}$, the ATP receptors of the AT II cells become desensitized and surfactant impairment is initiated. The resulting alteration in viscoelastic properties and in alveolar opening and collapse time-constants leads to alveolar collapse and the redistribution of inspired air from the alveoli to the alveolar ducts, which become pathologically dilated. The collapsed alveoli connected to these dilated alveolar ducts are subject to a massive strain, exacerbating the ATP release. After reaching concentrations $>300 \mu \mathrm{M}$ extracellular ATP acts as a danger-associated molecular pattern, causing capillary leakage, alveolar space edema, and further deactivation of surfactant by serum proteins. Decreasing the tidal volume to $6 \mathrm{~mL} / \mathrm{kg}$ or less at this stage cannot prevent further lung injury.
\end{abstract}

Keywords: extracellular ATP; purinergic signaling; P2X receptors; P2Y receptors; surfactant dysfunction; ventilation-induced lung injury; innate immunity 


\section{Introduction}

In 1929, Lohmann discovered and isolated adenosine triphosphate (ATP) from liver and muscles [1,2]. ATP is widely known as an intracellular molecule that is able to transfer energy and is indispensable in living cells [3,4]. Much later, extracellular ATP was identified and appeared to have a different function than the intracellularly located molecule. The intercellular signaling function of extracellular ATP has been described by Felberg and Hebb in 1948 in perfused cervical superior ganglion of the cat [5] and by Holton in 1959 in the sensory nerves of the rabbit ear [6]. In 1972 Burnstock wrote an article on the hypothesis of the purinergic co-transmission in neurons [7]. However, it took more than 20 years before the intracellular energy source ATP was recognized as an extracellular signaling molecule [8]. Now ATP is established as an important element of purinergic signaling in almost all tissues and the immune system [9].

It is well documented that potentially lifesaving mechanical ventilation may ironically damage the lungs and increase mortality risk in patients with acute respiratory distress syndrome (ARDS) by causing ventilation-induced lung injury (VILI) [10-13] and ARDS remains a serious clinical problem with mortality close to $40 \%$ [14]. Gattinoni, et al. (2016) found that it was not just the individual components of the mechanical breath (i.e., tidal volume, respiratory rate, driving pressure and positive end expiratory pressure-PEEP) that cause VILI but rather the mechanical power that the combination of these components generate [11]. Using continuous mandatory ventilation (CMV-volume control ventilation) with a tidal volume of $38 \mathrm{~mL} / \mathrm{kg}$ (corresponding to a strain of 2.5). Cressoni, et al. (2016) reported that, in piglets, lung injury cannot be provoked at a respiratory rate of $\leq 9 / \mathrm{min}$ corresponding to a mechanical power of $<12 \mathrm{~J} / \mathrm{min}$ [15]. Mechanical power of the ventilator is calculated by a formula. Tidal volume, respiratory system elastance, inspiratory-to-expiratory time ratio, airway resistance, respiratory rate and PEEP are include in the equation of the formula [11]. High power mechanical ventilation is defined as any mechanical breath, which exceeds $12 \mathrm{~J} / \mathrm{min}$ and corresponds to a mechanical ventilation settings with a tidal volume of $>38 \mathrm{~mL} / \mathrm{kg}$ ideal body weight and a respiratory rate of $\geq 12 / \mathrm{min}$ [15]. Reportedly, intratracheal administration of $400 \mu \mathrm{L}$ of $5.16 \mathrm{mM}$ ATP in rats leads to alveolar edema [16] and intratracheal instillation of $50 \mu \mathrm{L}$ of $100 \mathrm{mM}$ ATP or $200 \mathrm{mM}$ uridine triphosphate (UTP) in mice leads to diffuse alveolar damage resembling the effect of high power mechanical ventilation [17]. Recently, we reported that injurious mechanical ventilation results in vigorous cyclic mechanical deformations of the alveolar epithelial cells resulting in massive release of extracellular ATP from the alveolar epithelial type I (AT I) cell [10]. The high levels of extracellular ATP activate a pro-inflammatory immune response of the innate immune system through purinergic signaling [18-20] which causes diffuse alveolar damage (DAD) [10,17], the histopathology characteristic of VILI [21].

In this report, we centered on an important component of VILI: the impairment of the pulmonary surfactant function [22,23]. Multiple mechanisms for VILI-induced surfactant impairment in the absence of infection have been reported: (1) increased pulmonary vascular permeability resulting in pulmonary edema with high serum proteins. These serum proteins cause disaggregation and inactivation of surfactant [24], reducing the proportion of functional large aggregates (LAs) significantly in favor of the non-functional small aggregates (SAs) [22,23]; (2) High mechanical power ventilation may enhance the transport of alveolar surfactant into the airways [25,26]. However, these explanations do not account for the mechanism of increased surfactant in the lung lavage in the first two hours during mechanical ventilation with high mechanical power [22,27]. Additionally, the pathogenesis of VILI suggests a mechanism other than capillary leak as the initiating event: High mechanical power ventilation in rats causes surfactant composition changes with surfactant function impairment within one hour and a fall in lung compliance occurs within two hours [22], whereas capillary leak causing overt alveolar edema detected by a computed tomography (CT) scan does not develop for 2-14 h [28] and histological evidence of alveolar edema was not detected at two hours [29]. 
Therefore, we searched and studied the literature elaborately to find the explanation for the increased surfactant production and the development of surfactant impairment that precede the capillary leak, lung edema and the pro-inflammatory response of the innate immune system.

\section{Extracellular Release of ATP by AT I and AT II Cells and Clearance of Extracellular ATP}

In contrast to the relatively high ( 3 to $10 \mathrm{mM}$ ) intracellular concentrations of ATP in epithelial cells [30] the concentration of extracellular ATP in the medium around the $6 \mathrm{HBE} 14 \mathrm{o}^{-}$human bronchial epithelial cells [31] and in resting conditions measured in a cell culture of rat AT II cells [32] is much lower at about $2 \mathrm{nM}$ (Figure 1A). Mechanical deformation (tonic or cyclic stretching) during ventilation of the AT I cells activates the mechanosensitive P2X7 ATP receptors (P2X7Rs) causing a controlled extracellular release of ATP molecules (Figure 1B) [32,33]. In this case the P2X7Rs function as an ATP release channel [34] rather than an intrinsic cation channel or an ATP receptor initiating intracellular signal transduction (P2Y2R and P2X4R in Figure 1B).

Extracellular ATP molecules are converted by ATP-converting ecto-enzymes or by soluble extracellular enzymes to adenosine (Figure $1 \mathrm{~A}-\mathrm{C}$ ) [10,18]. The hydrolyzing enzymes are: Nucleoside triphosphate diphosphohydrolase 1 (NTPD1 or CD39, converts ATP to ADP and ADP to AMP), nucleotide pyrophosphatase/phosphodiesterase (NPP, converts ATP to AMP) and 5'-nucleotidase (5'-NT or CD73, converts AMP to adenosine). Soluble extracellular adenosine deaminase (ADA) converts a proportion of extracellular adenosine to inosine. The remaining adenosine molecule enters the cells via the equilibrative nucleoside transporters (ENT1 and ENT2) and concentrative nucleoside transporters (CNT1 and CNT2). Intracellular adenosine is converted to inosine, hypoxanthine, and AMP by the enzymes ADA, purine nucleoside phosphorylase (PNP) and adenosine kinase (ADK). This process maintains the homeostasis of extracellular ATP in the alveolar walls (Figure 1A-C [10,18].

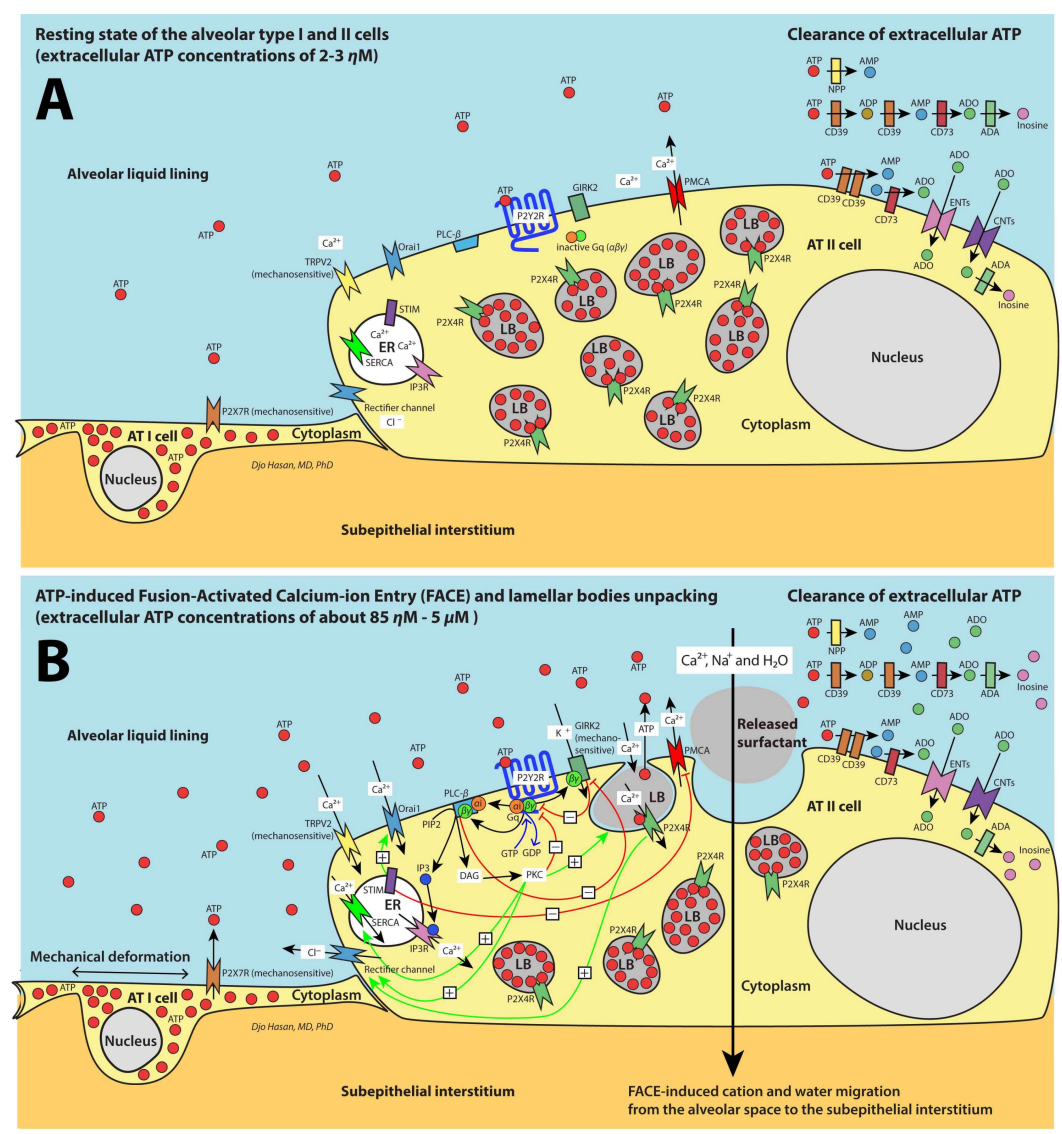

Figure 1. Cont. 


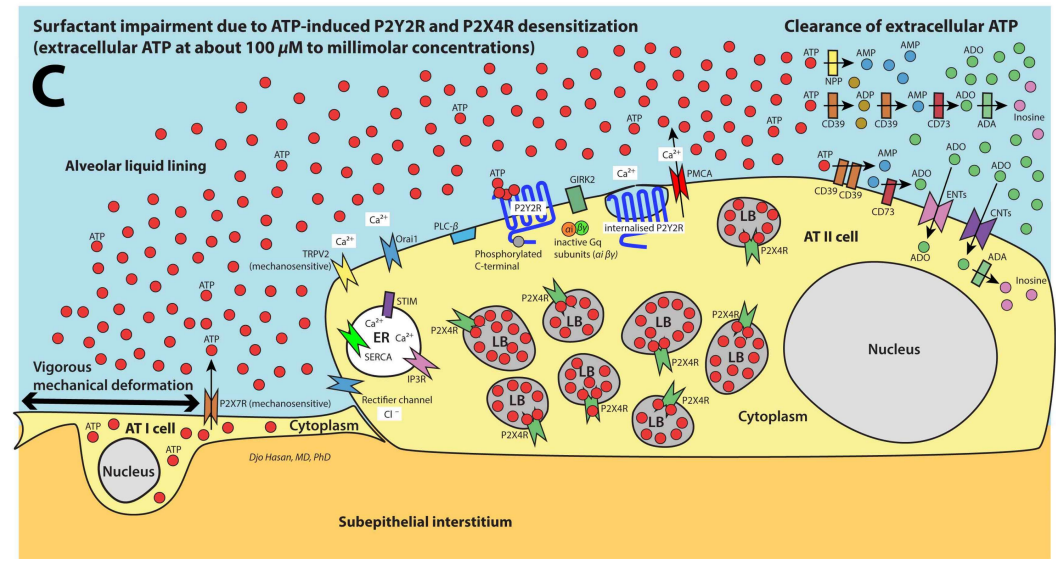

Figure 1. Schematic presentation of the regulation of surfactant exocytosis. For greater clarity, the high cytosolic adenosine triphosphate (ATP) content is omitted in the figure. (A) Resting state of the alveolar epithelial type I (AT I) and AT II cells. (B) ATP-induced fusion- activated calcium-ion entry resulting in surfactant exocytosis. (C) Excessive extracellular ATP concentrations causing the impairment of surfactant exocytosis. See text for explanation. AT I: Alveolar epithelial type I cell; AT II: Alveolar epithelial type II cell; ER: Endoplasmic reticulum; LB: Lamellar body; P2Y2R and P2X4R: ATP receptors; Gq/11: G protein-coupled receptor molecules comprising $\alpha \mathrm{i}$ and $\beta \gamma$ subunits; PLC- $\beta$ : Phospholipase C beta; PIP2: Phosphatidylinositol 4,5-bisphosphate; IP3: Inositol triphosphate; IP3R: Inositol triphosphate receptor, a membrane bound glycoprotein complex functioning as a $\mathrm{Ca}^{2+}$ channel sensitive to activation by IP3; STIM1: Stromal interaction molecule 1, a calcium sensor; Orai1: Calcium release-activated calcium channel protein 1, a calcium selective ion channel; TRPV2: Transient receptor potential cation channel subfamily $\mathrm{V}$ member 2 , a non-selective cation channel; Kir3: $\mathrm{K}^{+}$selective inwardly rectifying channel 3 or GIRK2: G protein-coupled inwardly-rectifying $\mathrm{K}^{+}$channel 2; DAG: diacylglycerol; PKC: protein kinase C; CD39: Nucleoside triphosphate diphosphohydrolase 1 (NTPD1); NPP: nucleotide pyrophosphatase/phosphodiesterase; CD73: 5'-nucleotidase (5'-NT); ADA: adenosine deaminase; ENTs: Equilibrative nucleoside transporters 1 and 2; CNTs: Concentrative nucleoside transporters 1 and 2; FACE: fusion-activated $\mathrm{Ca}^{2+}$ entry; SERCA: sarcoplasmic/endoplasmic reticulum $\mathrm{Ca}^{2+}$ ATPase channel; PMCA: Plasma membrane $\mathrm{Ca}^{2+}$ ATPase channel. Figures extensively adapted from Hasan, et al. (2017) [10] (open access) with permission.

\section{Purinergic Signaling Increases the AT II Cytoplasmic $\mathrm{Ca}^{2+}$ Levels by the Entry of Extracellular $\mathrm{Ca}^{2+}$ and Store-Operated $\mathrm{Ca}^{2+}$ Entry (SOCE)}

The extent of the extracellular release of ATP molecules by cyclic stretching of the lung is proportional to the strain (equivalent to the tidal volume), frequency and duration of the ventilation [32,33]. When the extracellular ATP concentrations reach the half maximum effective concentration $\left(\mathrm{EC}_{50}\right)$ of 85 to $230 \mathrm{nM}$ in human [35], ATP binds to and activates the P2Y2Rs at the AT II cell membranes (Figure 1B) [36]. This facilitates the coupling of the Gq/11 molecule (comprising $\alpha \mathrm{i}$ and $\beta \gamma$ subunits) to the G protein-coupled receptor (GPCR) structure of the P2Y2Rs. In the basal state, the heteromeric $\mathrm{Gq} / 11$ subunits are indissoluble. After coupling to the GPCR, Gq/11 subunits are activated. The activated $\alpha \mathrm{i}$ subunit releases a guanosine $5^{\prime}$-diphosphate (GDP) molecule and binds to a guanosine $5^{\prime}$-triphosphate (GTP) molecule followed by the dissociation of the $\alpha i$ and $\beta \gamma$ subunits initiating intracellular signal transduction [37]. The $\alpha \mathrm{i}$ and $\beta \gamma$ subunits activate phospholipase $C$ beta (PLC- $\beta$ ) to hydrolyze phosphatidylinositol 4,5-bisphosphate (PIP2) resulting in the formation of the second messengers diacylglycerol (DAG) and inositol triphosphate (IP3) [38]. IP3 binds with the IP3 receptors (IP3Rs, a membrane-bound glycoprotein complex functioning as a $\mathrm{Ca}^{2+}$ channel sensitive to activation by IP3) causing the release of $\mathrm{Ca}^{2+}$ by the endoplasmic reticulum (ER). This process is referred to as store-operated $\mathrm{Ca}^{2+}$ entry (SOCE). IP3Rs are important calcium release channels of SOCE [39]. The ryanodine receptor (another important SOCE $\mathrm{Ca}^{2+}$ release channel in skeletal 
muscle, smooth muscle, and cardiac muscle) is not expressed in the lung tissue [40]. SOCE causes $\mathrm{Ca}^{2+}$ store depletion that is sensed by the EF-hand and sterile $\alpha$ motif (EF-SAM) regions of Stromal interaction molecule 1 (STIM1, a calcium sensor). This information is transferred to activate the plasma membrane STIM1 Orai1-activating region/CRAC-activating domain (SOAR/CAD) regions through the cytoplasmic C-terminus 1 (CC1) regions of the STIM1 molecules located in the cytoplasm. Then the SOAR/CAD regions activate the calcium release-activated calcium channel protein 1 (Orai1) $\mathrm{Ca}^{2+}$ channels at the plasma membrane allowing extracellular $\mathrm{Ca}^{2+}$ molecules to enter the cytoplasm. STIM1 and Orai1 belong to the calcium release-activated calcium channel (CRAC) family (Figure 1B) [39].

Inward $\mathrm{Ca}^{2+}$ current is also generated though the mechanosensitive transient receptor potential cation channel subfamily V member 2 (TRPV2, a non-selective cation channel) during inspiration [41]. In addition, the $\mathrm{Gq} \beta \gamma$ subunits of the activated P2Y2Rs simulate (by a direct binding) the $\mathrm{K}^{+}$selective inwardly rectifying channel 3 (Kir3) or $\mathrm{G}$ protein-coupled inwardly-rectifying $\mathrm{K}^{+}$channel 2 (GIRK2) expressed on the AT II cell membrane [37]. Kir3 or GIRK2 is a mechanosensitive channel and can also be activated by mechanical deformation of the AT II cells (Figure 1B) [42]. Moreover, activation of the P2Y2Rs and the P2X4Rs induces the volume-regulated anion current channel (VRAC). One of the major components of VRAC is the outwardly rectifying $\mathrm{Cl}^{-}$channel that is sensitive to protein kinase C (PKC) activation [43,44]. DAG, phosphatidylserine (Ptd-Ser, a component of the AT II cell membrane) and $\mathrm{Ca}^{2+}$ are required for the activation of PKC. DAG strikingly increases the affinity of PKC for $\mathrm{Ca}^{2+}$ [45]. PKC binds with $\mathrm{Ca}^{2+}$ exposing a binding site for Ptd-Ser of the inner part of the cell membrane leading to a redistribution of PKC from the cytosol to the cell membrane [45]. This promotes the trafficking of the lamellar bodies (LBs), docking hemifusion and fusion of the LB membrane with the plasma membrane of the AT II cell (Figure 2A) [46]. After the development of a fusion pore, further pore expansion is accelerated by an additional elevation of cytoplasm $\mathrm{Ca}^{2+}$ levels resulting in the exocytosis of surfactant. It was first thought that the additional elevation in $\mathrm{Ca}^{2+}$ levels is achieved by extracellular ATP molecules that reach the P2X4Rs located at the LB membrane through the newly formed fusion pore [47,48]. But recently, it appeared that the LBs of rat AT II cells contains a high ATP level of about $1.9 \mathrm{mM}$ at a low $\mathrm{pH}$ of 5.5 [49]. ATP is transported from the cytosol to the LBs through the vesicular nucleotide transporter (VNUT) located on the LB membrane [50,51]. P2X4Rs are inwardly rectifying cation $\left(\mathrm{Na}^{+}\right.$and $\mathrm{Ca}^{2+}$ ) channels located at the membrane of the LBs (Figure 1B) [49]. At $\mathrm{pH}$ values lower than 7.4 [49] and at ATP concentrations $>100 \mu \mathrm{M}$ [52] the P2X4Rs are desensitized. Because the fusion pore connects the intravesicular space of the LBs with the extracellular space with a $\mathrm{pH}$ value of 7.4 and with low ATP concentrations, the intravesicular $\mathrm{pH}$ increases to 7.4 and ATP is released from the LBs to the extracellular space. This causes the intravesicular ATP levels to fall from $1.9 \mathrm{mM}$ to $1-5 \mu \mathrm{M}$ and within the window of the effective concentrations of the P2X4Rs (as shown in in human embryonic kidney 293-HEK293-cells [52]). This renders the P2X4Rs to become resensitized to ATP stimulation allowing $\mathrm{Ca}^{2+}$ ions to enter the cytoplasm (Figure 1B) $[52,53]$.

In addition, IP3 can be transported from AT II to other AT II cells, but direct communication between AT II cells can occur only by bridging the AT I cells that separate the AT II cells by means of tunneling nanotubes (TNTs) [54]. TNTs are long membrane projections with a diameter of 50 to $200 \mathrm{nM}$ and a length of up to $\sim 70 \mu \mathrm{M}$ (the size of several cells) [55]. TNTs are capable of transporting signals, organelles, and viruses between AT II cells in the presence of connexin gap junction protein isoform 43 (Cx43) [54]. Reportedly, both Cx43 and TNTs are expressed by the AT II cells [56] and intercellular communication through TNTs between alveolar AT II cells that express Cx43 can induce intercellular $\mathrm{Ca}^{2+}$ waves by the transmission of IP3 molecules [54]. This process and the activities of outwardly rectifying $\mathrm{Cl}^{-}$channels and $\mathrm{G}$ protein-coupled inwardly-rectifying $\mathrm{K}^{+}$channels 2 (GIRK2) reinforce the increase of AT II cytoplasmic $\mathrm{Ca}^{2+}$ levels through the paracrine stimulation of the P2Y2Rs by extracellular ATP and the autocrine stimulation of P2X4Rs by vesicular ATP (Figure 1B).

The time required for the LB fusion after the activation of the P2Y2Rs ranges from seconds to several minutes [46]. After the initial fusion pore has developed, a perivesicular F-actin coating is formed around the fused LBs (Figure 2A). This process is $\mathrm{Ca}^{2+}$-dependent [57]. Despite the accelerated 
increase in cytoplasm $\mathrm{Ca}^{2+}$ levels, surfactant exocytosis is a relatively slow process (lasting several minutes to hours) $[46,58]$. The amount of the released surfactant by the AT II cells is proportional to the extracellular ATP levels [32].
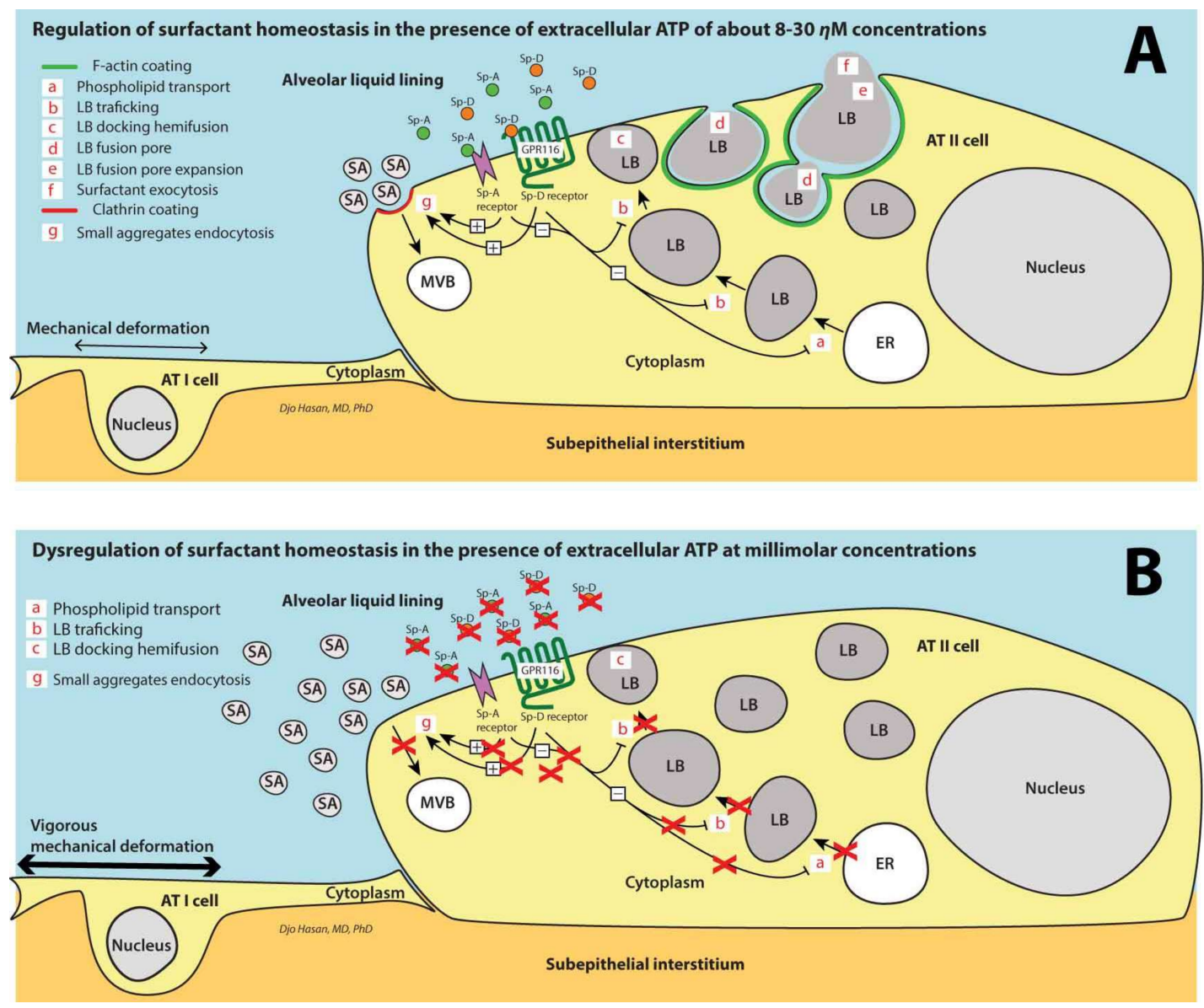

Figure 2. Schematic presentation of the surfactant homeostasis of the alveolar epithelial cells. (A) A perivesicular F-actin coating is formed around the fused LBs after the initial LB fusion pore has developed. Several types of fusion pore development are described [57]: (1) $80 \%$ of the F-actin-coated fused LBs release surfactant and the LB membrane becomes part of the plasma membrane (kiss-coat-and-release) followed by the disappearance of the F-actin coat; (2) 10\% of the F-actin-coated fused LBs discontinued the fusion process and returned inside the cell (kiss-coat-and-run); (3) In the remaining F-actin-coated LBs the fusion process was arrested for a certain time $(<20 \mathrm{~min})$ (kiss-coat-and-wait) [57]. The endocytosis of SAs occurs through a clathrin-dependent pathway [59] by the activation of several types of SP-A receptors [59-63] and a SP-D receptor [64]. The SP-D receptor is a GPR116, also known as Ig-Hepta that are highly expressed in the lung [64]. Besides SAs uptake, this process also inhibits the surfactant exocytosis and contributes to the control of extracellular surfactant homeostasis [59,64]. (B) The activation of the pro-inflammatory response of the innate immune system through the activation of the P2X7Rs by extracellular ATP at $>300 \mu \mathrm{M}$ concentrations (ATP molecules at these concentrations act as DAMPs) leads to the recruitment and activation of neutrophils. The recruited and activated neutrophils cause the degradation of SP-D and SP-A leading to a deficiency of SP-D and SP-A $[65,66]$ preventing the clathrin-dependent recycling of the majority of SAs and aborting the above-mentioned inhibition of the trafficking, semi-fusion and fusion of the LBs with the cell membrane. AT I: Alveolar epithelial type I cell; AT II: Alveolar epithelial type II cell; ER: Endoplasmic reticulum; LB: Lamellar body; MVB: multivesicular body; SP-A: Surfactant protein A; SP-D: Surfactant protein D; SAs: Surfactant small aggregates; LAs: Surfactant large aggregates; GPR116: G protein-coupled receptor 116; DAMPs: danger-associated molecular patterns. 


\section{Fusion of Lysosomes and LBs with the Plasma Membrane Plays a Role in the Repair of Damaged Plasma Membrane of the AT I and AT II Cells, Respectively}

Belete, et al. (2011) reported that the repair of damaged rat AT I cell monolayers by applying stretch assay or micropuncture assay is facilitated by the subsequent increase in extracellular ATP concentrations. At extracellular concentrations of about $10 \mu \mathrm{M}$ ATP activates the P2Y2Rs causing the fusion of the membrane of lysosomes with the plasma membrane releasing the lysosomal-associated membrane protein 1 (LAMP-1) and replacing the damaged plasma membrane [67]. The application of apyrase (CD39) that converts ATP to ADP and AMP and after silencing of the expression of P2Y2Rs the plasma membrane repair rate are reduced significantly [67]. We think that similar repair process of the AT II plasma membrane may occur following the fusion of LBs with the plasma membrane.

\section{FACE Causes a Trans-Epithelial Transport of $\mathrm{Na}^{+}, \mathrm{Ca}^{2+}$ and Water Molecules}

Besides surfactant exocytosis, FACE causes a trans-epithelial transport of $\mathrm{Na}^{+}$and $\mathrm{Ca}^{2+}$ molecules from the alveolar space through the P2X4Rs and the cytoplasm of the AT II cells to the sub-epithelial interstitial space. This is followed by a passive water resorption from the alveolar liquid lining to the sub-epithelial interstitial space (Figure 1B). Together with the transepithelial transport of $\mathrm{Na}^{+}$(through the epithelial $\mathrm{Na}^{+}$channel-ENaC) and $\mathrm{Cl}^{-}$(through the cystic fibrosis transmembrane conductance regulator-CFTR) [68] FACE keeps the alveolar liquid lining as thin as $200 \mathrm{nM}$ with a high density of surfactant phospholipid membranes [48]. The thin alveolar liquid lining promotes the contact between the highly organized multilayer surfactant LAs that are stored in the hypophase beneath the surface active monolayer interfacial film and the surfactant monolayer itself. This facilitates the adsorption of surfactant from the multilayer LAs to the surfactant monolayer film [48]. The surface active monolayer interfacial film forms the basis for an optimal diminution of the surface tension of the air-liquid interface in the alveolar space [69].

\section{Surfactant Remodeling in the Alveolar Space}

In the alveolar space, surfactant aggregates undergo a remodeling process forming LB-like surfactant compositions and tubular myelin, a lattice-like arrangement of surfactant phospholipid molecules with SP-A and SP-B molecules. These highly organized multilayer surfactant LAs in the extracellular hypophase are thought to be indispensable during the ventilation-induced expansion (inflation) for the adsorption of the phospholipid molecules to the surface active monolayer film at the air-liquid interface (interface film layer) in the alveolar space [69]. SP-B and SP-C are indispensable for the adsorption process $[70,71]$ and this process is followed by the spreading of the surfactant molecules in the interface film layer [69]. Additionally, the transport of oxygen molecules in a water layer containing SP-B and SP-C-mediated densely packed lipid membranes is significantly faster than through a pure water layer or a water layer with pure phospholipid membranes [72].

At the beginning of the ventilation-induced compression (deflation) the surfactant molecules in the interface film are not densely packed and still have space to condense causing a rather steep drop in surface tension. Then as deflation progresses the interface monolayer becomes saturated with phospholipid molecules and starts to collapse forming an inward [73,74] or outward [75] buckling of surfactant bilayers. The outwardly buckled surfactant molecules form bilayer disks that rest above the monolayer [75]. These bilayer disks can either be reincorporated into the monolayer [75] or converted to non-functional SAs and lost into the alveolar space and airways [26,69]. Similarly, part of the inwardly buckled surfactant bilayers may be reincorporated into the interface monolayer during the adsorption process or may form new multilayer LAs in the hypophase or may be converted to non-functional SAs [69]. 


\section{Surfactant Homeostasis in the Alveolar Space}

About $10 \%$ of the total surfactant molecules is lost and replenished each hour [69]. A small proportion $(7-15 \%)$ is cleared through the airways $[25,26,69]$ presumably after the collapse of the interface monolayer through outward buckling [75] and $20 \%$ is cleared by macrophages promoted by GM-CSF (granulocyte-macrophage colony stimulating factor) [69]. A very small proportion of surfactant proteins can be detected in the blood [76], but the majority of the "spent" surfactant (about $65 \%$ ) is taken up by the AT II cells through endocytosis to be recycled [69]. Under basal conditions, SA endocytosis is executed through a clathrin-independent pathway [59]. In contrast, in the presence of secretagogues such as extracellular ATP the uptake of SA is dependent on the clathrin pathway and on both extracellular SP-A and SP-D levels (Figure 2A) [59].

Several SP-A-binding proteins at the cell membrane of the AT II cells are reported: (1) SP-A receptors that bind to A2C and A2R monoclonal anti-idiotype antibodies (SPARs) [60]; (2) surfactant-binding protein BP55 [61]; (3) SP-A receptor with a 50-kD protein core that binds SP-A in a calcium-dependent manner not involving the mannose-binding region of SP-A [62]; (4) a 210-kDa SP-R210 [63]; (5) SP-A receptor that is identified as type II transmembrane protein p63 (CKAP4/p63) [59]. Additionally, another receptor that is involved in SA endocytosis is reported: the GPR116 (Figure 2A) [64]. GPR116 is also known as Ig-Hepta which has Ig-like repeats in the $\mathrm{N}$-terminal extracellular domain and is highly expressed in the lung [64]. GPR116 is thought to be an orphan GPCR carrying an agonistic protein sequence (Stachel sequence) that functions as a tethered agonist after the removal or a structural change of the $\mathrm{N}$-terminal from the C-terminal fragment of the Stachel sequence [77]. Recently, the activation of the GPR116 by synthetic peptides resembling the C-terminal fragment has been reported [77]. In addition, SP-D may function as a ligand activating the GPR116 [64]. Increased SP-D levels in the alveolar liquid lining activate GPR116s. Thus SP-A and SP-D activate the clathrin-dependent 'spent' SA uptake and apparently inhibit the exocytosis of surfactant contributing to the control of extracellular surfactant homeostasis in the alveoli (Figure 2A) [59,64].

\section{Clearance of $\mathrm{Ca}^{2+}$ Ions from the Cytoplasm}

Clearance of the $\mathrm{Ca}^{2+}$ from the AT II cytoplasm occurs by re-entering the endoplasmic reticulum (ER) through sarcoplasmic/endoplasmic reticulum $\mathrm{Ca}^{2+}$ ATPase channels (SERCAs) that can transfer $\mathrm{Ca}^{2+}$ from the cytoplasm to the ER using energy from ATP hydrolysis $[78,79]$ and/or by leaving the cell through Plasma membrane $\mathrm{Ca}^{2+}$ ATPase channels (PMCAs) that are capable of transferring $\mathrm{Ca}^{2+}$ from the cytoplasm to the extracellular space (Figure 1B) [80]. Isoforms of both SERCA and PMCA are expressed in the lung $[78,80]$. Under resting conditions, SERCA is bound to phospholamban (SERCA-PLB complex) and the ATPase activity is inhibited. Activation of SERCA-PLB complex occurs after the cytoplasm levels of $\mathrm{Ca}^{2+}$ reach micromolar concentration or after phosphorylation by PKC followed by a partial dissociation of PLB from SERCA [81]. In contrast, PMCA is active under resting conditions and is attenuated by activated STIM1 (Figure 1B) [82]. Restored $\mathrm{Ca}^{2+}$ ER levels terminate the stimulation of STIM1 allowing $\mathrm{Ca}^{2+}$ ions to be released to the extracellular space. Very high activity of PKC and GIRK2 causes the phosphorylation of the intracellular C-terminal tail of the P2Y2R GPCR molecules causing the ATP receptor to be desensitized (Figure 1B,C) [83,84]. GIRK2 can be inhibited by PLC $\beta$ through depletion of PIP2 and activation of PKC (Figure 1B) [42]. These processes control the cytoplasmic $\mathrm{Ca}^{2+}$ levels.

\section{Ventilation-Induced Extracellular ATP: (1) Initially Increases the Surfactant Release, (2) Halts Surfactant Release and Plasma Membrane Repair at $>100 \mu$ M Concentrations and (3) Triggers the Pro-Inflammatory Response of the Innate Immunity at $>300 \mu \mathrm{M}$ Concentrations}

Mechanical ventilation with high mechanical power $(>12 \mathrm{~J} / \mathrm{min}$ ) causes vigorous cyclic deformation of the AT I and AT II cells followed by an increased release of extracellular ATP [10]. This proportionally increases the release of surfactant [32] and explains the increase in LA levels in bronchoalveolar lavage fluids (BALFs) in the first hour during ventilation with high mechanical 
power [22]. Martinez, et al. (2004) confirmed the increase in surfactant exocytosis and increase in respiratory compliance in the first hour of ventilation with high mechanical power in newborn rats [27]. We postulate that after one hour the purinergic receptors of the surfactant release mechanism become desensitized (Figure 1C). The mechanism for this desensitization could be explained if extracellular levels of ATP reached $\geq 100 \mu \mathrm{M}$ : In-vitro exposure of rat glomerular mesangial cells P2Y2Rs to 100 $\mu \mathrm{M}$ ATP during 2 min decreased the sensitivity to stimuli within $1 \mathrm{~min}$. P2Y2Rs reached their maximum desensitization to stimuli within 2 to $4 \mathrm{~min}$. Repetitive stimuli with an interval of $7 \mathrm{~min}$. led to increasingly weaker responses [85]. Desensitization of the P2Y2Rs occurs through two distinct mechanisms: (1) Phosphorylation of the intracellular C-terminal tail of the P2Y2R GPCR by GIRK2 or by PKC. This prevents the coupling of Gq $\alpha$ and Gq $\beta Y$ subunits to the P2Y2R GPCR [84]; (2) Internalization of the P2Y2Rs rendering the receptor inaccessible to ATP binding through an unknown pathway [86]. In HEK293 cells desensitization of the P2X4Rs occurs faster within seconds after a stimulus with $100 \mu \mathrm{M}$ ATP and being maximally desensitized within 30 to $60 \mathrm{~s}$ [52]. The mechanisms of desensitization are: (1) Allosteric change of the P2X4R molecules decreasing the $\mathrm{Ca}^{2+}$ pore dimensions [53]; (2) Internalization of the P2X4Rs regulated by Rab5 (a small Ras-like GTPase 5) that promote membrane invagination leading to the endocytosis of P2X4Rs through the clathrin pathway [87]. After desensitization, these receptors become unresponsive to ATP stimuli followed by the absence of cytoplasmic $\mathrm{Ca}^{2+}$ response to mechanical deformation of the AT I and AT II cell abolishing the surfactant exocytosis by the AT II cells. Therefore, extracellular ATP concentrations $>100 \mu \mathrm{M}$ desensitize the P2Y2Rs at the plasma membrane of AT II cells and prevent the resensitization of the P2X4Rs in the membrane of LBs leading to the impairment of the surfactant release to the extracellular space. Diminishing surfactant exocytosis involves the disappearance of the FACE-induced trans-epithelial transport of $\mathrm{Na}^{+}, \mathrm{Ca}^{2+}$ and water molecules from the alveolar space to the interstitium (Figure 1B,C). Consequently, the thickness of the alveolar liquid lining increases, reducing the density of surfactant phospholipid membranes in the hypophase. This diminishes the contact between both the highly organized multilayer surfactant LAs in the hypophase and the surface active monolayer interfacial film. Obviously, this process contributes to the impairment of surfactant function. We postulate that in addition to a halt in the fusion process of LBs with the plasma membrane of AT II cells, the fusion of lysosomes with the plasma membrane of AT I cells is also inhibited by the desensitization of the P2Y2Rs affecting the capacity of the AT II and AT I cells to repair plasma membrane damage.

In addition, increasing extracellular ATP levels results in the up-regulation of the ecto-enzymes and soluble extracellular ATP-converting enzymes CD39 and CD73 leading to a significant increase in extracellular adenosine levels [88]. However, the massive release of ATP in high mechanical power ventilation probably exceeds the capacity of these ATP-converting enzymes to convert ATP molecules. The effective extracellular ATP concentrations to activate the P2X7Rs (in JJ4 macrophage cells and in HEK cells expressing P2X7Rs) starts at about 300 to $1000 \mu \mathrm{M}$, [89]. In contrast to the P2Y2Rs and P2X4Rs, the P2X7Rs are not subject to desensitization at millimolar or higher extracellular ATP concentrations [89]. P2X7Rs are located at the cell membranes of many immune cells enabling ATP molecules to act as danger associated molecular patterns (DAMPs) activating the pro-inflammatory response of the innate immune system [10,18-20]. The recruited and activated neutrophils degrade the SP-D and SP-A molecules through a neutrophil serine protease-dependent cleavage and lead to a deficiency of SP-D and SP-A $[65,66]$. This prevents the recycling of the majority of SAs (Figure 2B) [59,64]. Under nanomolar concentrations of extracellular ATP deficiency of SP-A and SP-D aborts the inhibition of the surfactant exocytosis (Figure 2A). However, at $>100 \mu \mathrm{M}$ extracellular ATP concentrations the desensitization of the P2Y2Rs and P2X4Rs prevents surfactant release (Figure 2B). The consequences at this stage are that there is a relative increase of non-functional SAs compared to functional LAs and a depletion of LAs in the alveolar space. 


\section{Surfactant Deactivation Develops Significantly before Alveolar Space Flooding Caused by Increased Capillary Permeability}

As mentioned above, it is generally assumed that alveolar exudate of serum proteins explains the deactivation of surfactant function [24] and the development of overt lung edema [15]. However, the group of Lachman (2017) reported that ventilation with high mechanical power for two hours in rats causes a steady increase in the serum C3a levels and a significant increase in lung weight, although the histology of the lung tissue revealed characteristics of diffuse lung injury and a profound interstitial edema they found very little alveolar edema [29]. In addition, Cressoni, et al. (2015) found that alveolar edema as depicted by serial CT scanning as newly developed densities occurs not earlier than 2.1 to $14.7 \mathrm{~h}$ [28].

We explain this phenomenon by the following consecutive processes: First, because cytokine levels in mice lung tissue homogenate do not increase earlier than one hour of mechanical ventilation [90] and because the serum complement C3a levels are increased after one hour of high power mechanical ventilation [29], we assume that it takes at more than one hour for the extracellular ATP to reach concentrations $>300 \mu \mathrm{M}$ required to activate the P2X7Rs of the immune cells and initiate the pro-inflammatory response of the innate immune system. Second, shortly after the activation of the pro-inflammatory response of the innate immunity, complement components are produced by many cells of the immune system. Induction of the activity of complement C5a and C3a in-vitro by moderate concentrations of zymosan $(0.01 \mathrm{mg} / \mathrm{mL})$ starts immediately and requires eight hours to reach the maximum level of activation [91]. The small complement fragments C5a and C3a increase vascular permeability in rabbit skin causing capillary leakage of fluid leading to interstitial lung edema [92]. Third, the tight junctions between alveolar epithelial cells in the lung (consisting of different types of claudins, zonula occludens-1, occludin, etc.) are an important barrier against exudate formation in the alveolar space [93] and claudin- 4 and claudin-18 are expressed in the lung tissue [94]. Wray, et al. (2009) reported that the expression of claudin-4 is increased in the course of three hours of mechanical ventilation with a tidal volume of $20 \mathrm{~mL} / \mathrm{kg}$ [95]. Fourth, the transcription, activation and extracellular release of IL-1 $\beta$ and the IL- $1 \beta$-dependent production and activation of matrix metalloproteinase 9 (MMP-9) causing the degradation of the tight junctions proteins zonula occludens- 1 and occludin [96] requires additional time. This also applies to the P2X7Rs induced-increase in GSK-3 $\beta$ (glycogen synthase kinase $3 \beta$ ) protein levels that reduce the claudin-18 protein levels [94]. Inhibition of the claudin-4 function results in marked increase in alveolar space edema [95].

Therefore, although the interstitial edema caused by capillary leakage occurs immediately after the initialization of the pro-inflammatory response of the innate immune system the breakdown of the tight junctions requires more time. This breakdown of the tight junctions enables the interstitial fluid to reach the alveolar space leading to alveolar edema. This explains the observations that interstitial edema precedes alveolar space flooding by hours $[28,29]$ and provides the evidence that surfactant function impairment that occurs at $2 \mathrm{~h}$ after the initiation of high power mechanical ventilation in rats [22] is not caused by the disaggregation of surfactant LAs by the extravasated serum containing serum proteins. This rather early surfactant impairment can be explained by the halted FACE-induced trans-epithelial transport of $\mathrm{Na}^{+}, \mathrm{Ca}^{2+}$ and water molecules as mentioned above.

\section{Surfactant Impairment Causes Changes in Alveolar Mechanics Exacerbating the Release of Extracellular ATP}

We postulate that the magnitude of the extracellular release of ATP molecules by the mechanical deformation of the alveolar epithelial cells during continuous mandatory ventilation with high tidal volumes and low respiratory rate is such that the capacity of the soluble and ecto-enzymes is sufficient to maintain the extracellular ATP within the concentration range of $85 \mathrm{nM}$ to well below $100 \mu \mathrm{M}$. Increasing the respiratory rate to reach a mechanical power of $>12 \mathrm{~J} / \mathrm{min}$ boosts the extracellular ATP release beyond the capacity of the extracellular ATPases (CD39, NPP and CD73) to clear and the extracellular ATP levels gradually increase reaching $>100 \mu \mathrm{M}$ and $>300 \mu \mathrm{M}$ concentrations, resulting 
in surfactant impairment and VILI, respectively $[10,17]$. Thus, the healthy lung with intact surfactant function can withstand a strain of 2.5 fairly well [15] as long as the extracellular ATP levels remain below the levels that cause the desensitization of the P2Y2Rs and the PX4Rs $[52,85]$.

Using a synchrotron refraction-enhanced computed tomography Sera, et al. (2013) showed that in the healthy murine lung inflation of the lung by increasing the airway pressure from 0 to $8 \mathrm{~cm}$ $\mathrm{H}_{2} \mathrm{O}$ changes the alveolar duct diameter and not the alveolar space dimensions. At higher airway pressures, the alveolar ducts diameter remains constant and the alveolar space dimensions increase [97]. Therefore, despite the surfactant-induced decrease in surface tension the alveoli require adequate pressure to increase their diameter.

In addition to pressure, time is required to inflate the alveoli [98]. This phenomenon is described as the viscoelastic properties of lung tissue by Suki and Bates [99]. The time and the pressure that are required to inflate the alveoli are proportional to the surface tension. The higher the alveolar surface tension the longer the time and the higher the airway pressure that is required for the alveoli to be inflated [98,99]. After surfactant deactivation by saline lavage, a pressure of $40 \mathrm{~cm} \mathrm{H}_{2} \mathrm{O}$ over a 2 second period is required to recruit $80 \%$ of collapsed alveoli and $40 \mathrm{~s}$ to recruit the remaining alveoli [98]. At lower pressures and shorter time intervals, alveoli are not recruited as tidal volume is redistributed towards the alveolar ducts causing a tremendous enlargement of their size [100]. The dramatic increase in the alveolar duct diameter can be explained by the fact that there are 480 million alveoli [101] and 5600 acinar airways including the alveolar ducts [102] with an alveolar:alveolar duct ratio of 2.9 [100]. Redistribution of the tidal volume from the alveoli into the alveolar ducts results in extremely dilated alveolar ducts and pathologic stretching of the alveolar walls of the adjacent alveoli [100].

Moreover, alveoli are not only subject to the viscoelastic properties of the lung during inflation, but also during deflation. Satalin, et al. (2016) reported in a surfactant-deactivated lung that there is a lag time of $0.17 \mathrm{~s}$ before alveoli begin to collapse after the termination of the inspiratory phase. Furthermore, it takes $0.25 \mathrm{~s}$ before the alveoli fully collapse (Figure 3) [103]. This study demonstrated that the very short expiratory duration using the time-controlled adaptive ventilation (TCAV) protocol (corresponding with the APRV75\% group in Figure 4) is critical in normalizing air distribution within the alveoli and alveolar duct in a rat Tween-induced ARDS model and is supported the study by Kollisch-Singule, et al. (2014) and illustrated in Figure 4 [100]. If the expiratory duration is longer than the alveolar collapse-time, these newly recruited alveoli will derecruit with each expiration (Figures 3 and 4); if set shorter than the alveolar collapse-time the alveoli will remain inflated during the brief expiration period (Figures 3 and 4) [100]. Thus, the TCAV protocol stabilizes alveoli by two mechanisms: pressure and time. Therefore, although ventilation with low mechanical power $(<12 \mathrm{~J} / \mathrm{min})$ does not cause lung injury in healthy lung [15], ventilation with very low mechanical power corresponding with a tidal volume of $6 \mathrm{~mL} / \mathrm{kg}$ ideal body weight is injurious for the surfactant-deactivated lung (Figure 3) $[100,104]$. The efficacy of the TCAV protocol was recently demonstrated in experimental pulmonary and extrapulmonary ARDS [105]. The DAD score (reflecting the extent of pulmonary damage) and the expression of biological markers for lung tissue damage (i.e., amphiregulin, vascular cell adhesion molecule 1-VCAM-1, syndecan 1, metalloproteinase 9-MMP9 and decorin) are significantly higher in volume controlled ventilation (VC) with $8 \mathrm{~mL} / \mathrm{kg}$ ideal body weight than in TCAV [105].

In this perspective, the consequences of mechanical ventilation on the surfactant-deactivated lung are: First, if the pressure and the duration of the inspiration are inadequate to expand the alveoli tidal volume will be distributed towards the alveolar ducts. This increases the deformation of the alveolar epithelial cells of the adjacent alveoli that are connected to these alveolar ducts tremendously and augments the release of extracellular ATP to a level beyond the capacity of the ATPase enzymes (CD39, NPP and CD 73). ATP will gradually reach $>100 \mu \mathrm{M}$ concentrations causing surfactant impairment and $>300 \mu \mathrm{M}$ concentrations invoking the pro-inflammatory response of the innate immune system injuring the lung tissue. Bellingan, et al. (2014) reported that treatment with interferon-beta-1a (IFN- $\beta-1 \mathrm{a})$ that up-regulates the expression of CD73 reduces the ARDS mortality [106]. Second, even after a successful 
recruitment maneuver (RM) the newly recruited alveoli will collapse and reopen during every breath if PEEP is not set correctly since the expiratory duration with continuous mandatory ventilation is longer than the alveolar collapse-time.

The difficulty of opening the lung with a RM and attempting to stabilize it with PEEP was demonstrated in a recent publication by Cavalcanti, et al. (2017) and the "the Alveolar Recruitment for Acute Respiratory Distress Syndrome Trial (ART) Investigators" [107]. They reported a study of patients with moderate to severe ARDS. The patients are randomized into a control and an experimental treatment group. The control arm received ventilation with low tidal volume according to the ARDSNet protocol. The experimental strategy arm received the same low tidal volume protocol as the control group with the addition of neuromuscular blockade and RMs with incremental PEEP up to plateau pressure levels of $50 \mathrm{~cm} \mathrm{H}_{2} \mathrm{O}$ followed by a decremental PEEP trial to identify the PEEP level with the highest respiratory compliance. The mean PEEP level in the control group was $12.2 \mathrm{~cm} \mathrm{H}_{2} \mathrm{O}$ and $16.8 \mathrm{~cm}$ $\mathrm{H}_{2} \mathrm{O}$ in the experimental group. The mean plateau pressure in the experimental group was higher than in the control group but was always below $30 \mathrm{~cm} \mathrm{H}_{2} \mathrm{O}$. There is a slight but statistically significant higher mortality in the experimental group compared to the control group (55.3\% vs. 49.3\%) [107]. The RMs in the treatment group may open the lung initially, but soon after the termination of the RMs, the newly recruited alveoli recollapse due to an inadequate PEEP level. Therefore, the investigators opened up the lungs during the RM but the level of PEEP failed to keep the lung open thereafter, providing one explanation for the lack of benefit observed in the experimental group.

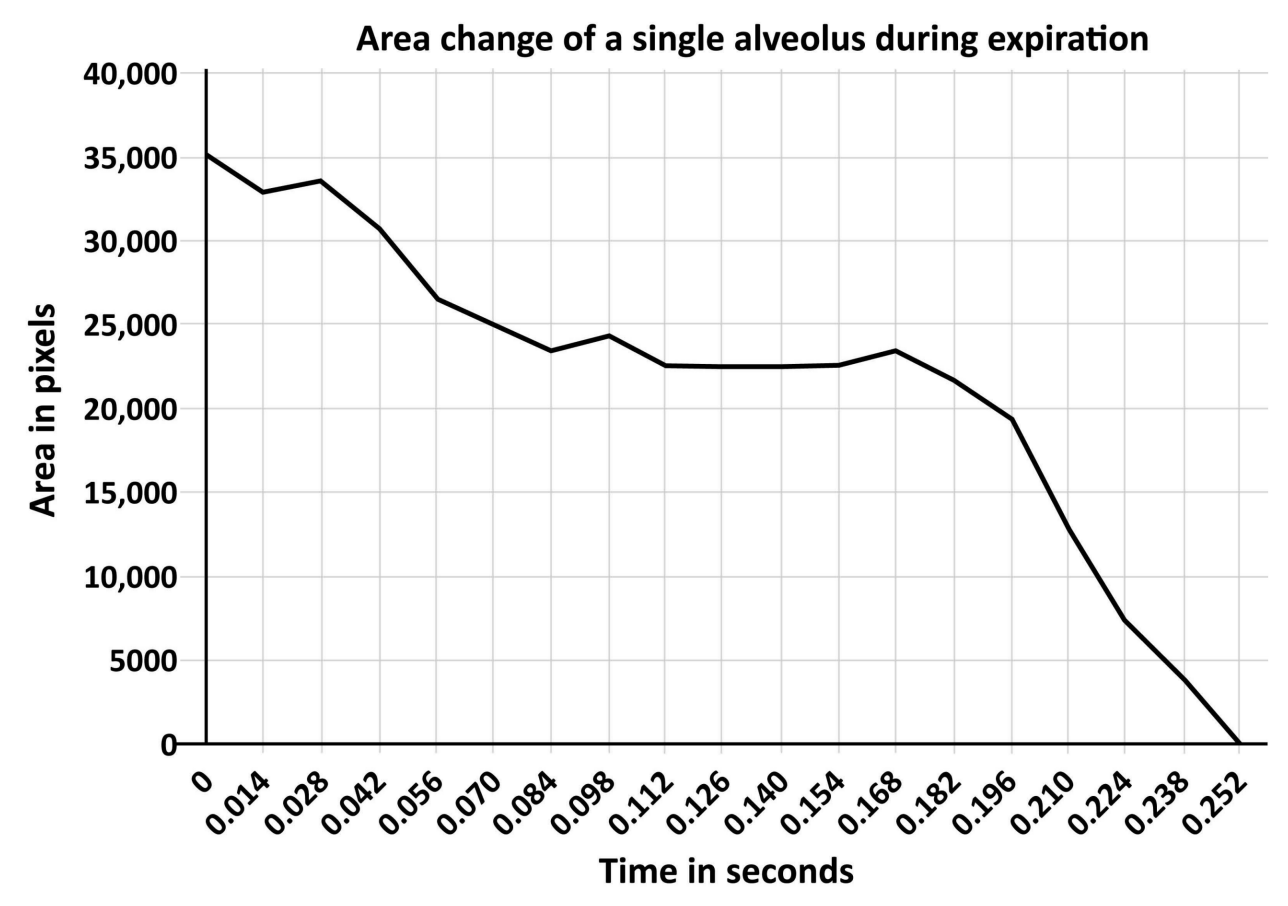

Figure 3. Graphic presentation of the time course of alveolar collapse during the expiration by releasing an airway pressure of $25 \mathrm{~cm} \mathrm{H}_{2} \mathrm{O}$ to zero as depicted by in-vivo microscopy in rats with surfactant-deactivated lung. The $\mathrm{Y}$-axis represents the alveolar surface areas in pixels and the $\mathrm{X}$-axis is the time. There is a time lag of $0.17 \mathrm{~s}$ before alveoli start to collapse after the initiation of the expiratory phase. Furthermore, it takes $0.25 \mathrm{~s}$ before the alveoli are fully collapsed. Figure from Satalin, et al. (2016) [103], presented at 'The Open Forum Sessions' during the AARC Congress 2016. 


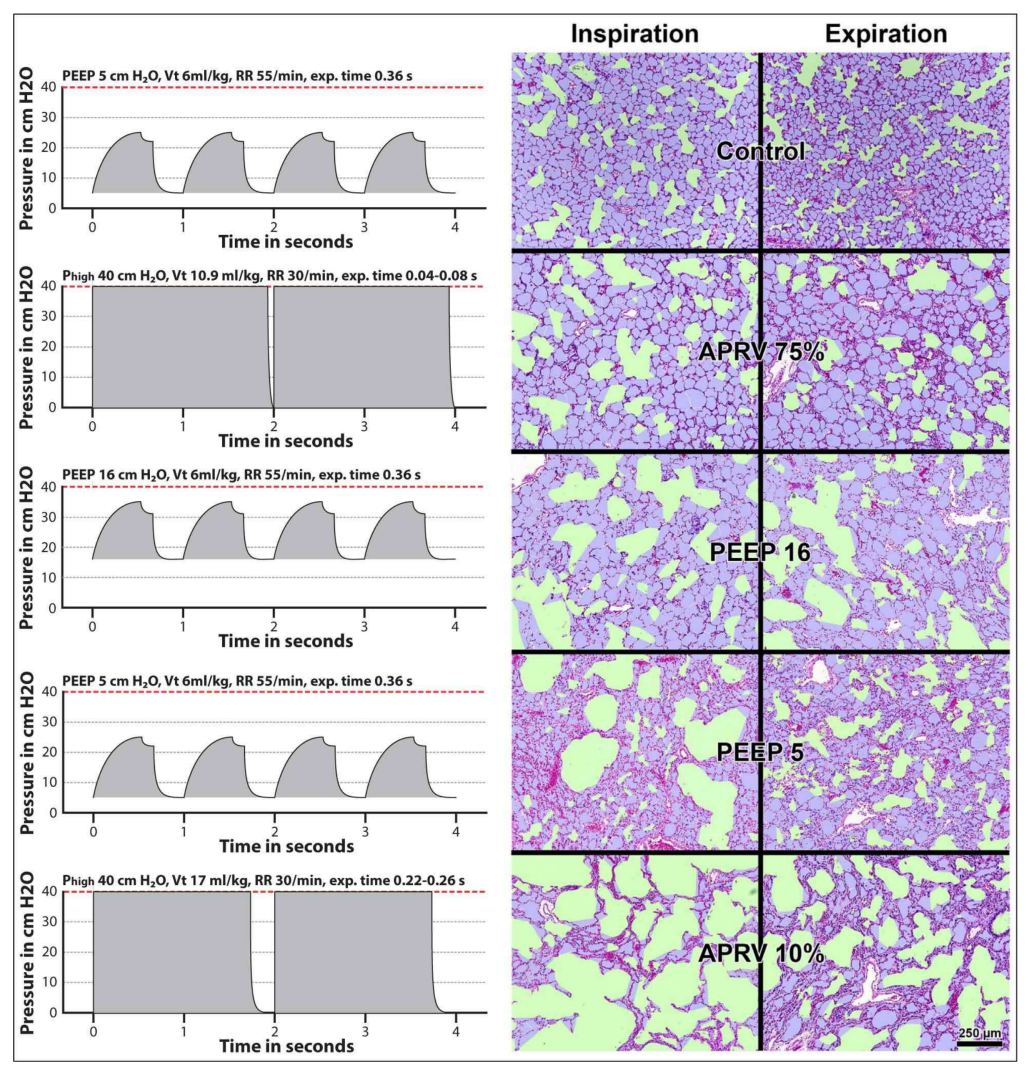

Figure 4. The effect of the ventilator settings on the alveolar mechanics. The left graphics are schematic presentations of the ventilator pressure-time curves belonging to the photomicrographs of the lung presented on the right figure. The lung was fixed at the end-inspiratory pressure (left column of the photomicrographs) and at the end-expiratory pressure (right column of the photomicrographs). The conducting airspaces including the alveolar ducts are colored green, the alveolar spaces are magenta and the alveolar walls are lilac. In APRV75\% and APRV10\% termination of the expiration is set at an EEF/PEF ratio of $75 \%$ and $10 \%$, respectively. In the healthy lung using tissue microscopy after fixing the lung at peak-inspiration and at end-expiration, Kollisch-Singule, et al. (2014) demonstrated that the distribution of tidal volume between the alveoli and the alveolar ducts shows little change during inspiration and expiration ('control') [100]. After surfactant deactivation, there is a redistribution of air at the end of expiration from the alveoli towards the alveolar ducts ('expiration' and 'PEEP 5'). During inspiration, the redistribution towards the alveolar ducts markedly increases causing a tremendous deformation of the alveoli adjacent to these alveolar ducts ('inspiration' and 'PEEP 5'). This results in an increased microstrain (defined as the change in length of the alveolar ducts between inspiration and expiration normalized by their original length). Increasing the PEEP level to $16 \mathrm{~cm}_{2} \mathrm{O}$ decreases the microstrain but not the redistribution of air towards the alveolar ducts ('Inspiration', 'expiration' and 'PEEP 16'). The application of APRV10\% with a $\mathrm{P}_{\text {high }}$ of $40 \mathrm{~cm} \mathrm{H}_{2} \mathrm{O}$ and expiratory time of $0.22-0.26 \mathrm{~s}$ increases the redistribution of air towards the alveolar ducts and the microstrain dramatically ('Inspiration', 'expiration' and 'APRV10\%'). By applying APRV75\% with a $\mathrm{P}_{\text {high }}$ of $40 \mathrm{~cm} \mathrm{H}_{2} \mathrm{O}$ with a shorter expiration time of 0.04 to $0.08 \mathrm{~s}$ the redistribution of air towards the alveolar ducts and the microstrain much improve but are still not completely restored ('Inspiration', 'expiration' and 'APRV75\%') [100]. Thus: in surfactant deactivated lung, a short expiratory time stabilizes the alveoli and a long expiratory time allows alveolar collapse to occur. By setting the timing of the termination of the expiration relative the $\mathrm{PEF}$, the actual expiration time will change proportional to the time-constant of the alveoli. For instance, in slowly deflating alveoli a longer time is required to reach an EEF/PEF ratio of $75 \%$ than in fast deflating alveoli. Consequently, the expiration time in a lung with a high compliance is longer than in a lung with a low compliance. Therefore, this mode is now referred to as the 'time-controlled adaptive ventilation' (TCAV). APRV: airway pressure release ventilation; EEF: end-expiratory flow; PEF: peak-expiratory flow; $\mathrm{P}_{\text {high }}$ : inspiratory pressure; PEEP: positive end expiratory pressure; Vt: tidal volume; RR: respiratory rate; Exp: Expiratory. Photomicrographs figure from Kollisch-Singule, et al. (2014) [100] with permission. 


\section{Summary and Conclusions}

In the healthy lung, continuous mandatory ventilation with high mechanical power causes an increase in mechanical deformation of the AT I cells followed by an increase in the release of extracellular ATP. This then functions as a signaling molecule for the AT II cells to release surfactant. However, at about $100 \mu \mathrm{M}$ concentrations, extracellular ATP receptors of the AT II cells become desensitized, surfactant release is halted, and the FACE-induced trans-epithelial transport of $\mathrm{Na}^{+}$, $\mathrm{Ca}^{2+}$, and water molecules from the alveolar space to the interstitium is diminished, thickening the alveolar liquid lining and impairing the surfactant function. At $300 \mu \mathrm{M}$ concentrations and above, extracellular ATP initiates the pro-inflammatory response of the innate immune system with immediate increased complement $\mathrm{C} 3$ levels causing capillary leakage followed by the disruption of the intercellular junctions of the alveolar epithelial cells, causing overt alveolar space edema. Surfactant disaggregation by serum proteins further deactivates the surfactant function, leading to a significant alteration in the viscoelastic properties of the lung and the redistribution of the tidal volume towards the alveolar ducts. This boosts the extracellular release of ATP by the alveolar epithelial cells and the pro-inflammatory response of the innate immune system. In addition, the initiated pro-inflammatory response of the innate immunity injuring the lung is followed by a reactive adenosynergic immune paralysis of the immune system and fibrosis [10]. Although extracellular ATP levels can be reduced by a treatment with IFN- $\beta-1 \mathrm{a}$, this may increase adenosine levels.

Future research should be directed into blocking high levels of extracellular ATP combined with improved ventilation strategies. Furthermore, new monitoring systems have to be developed to assess markers of the massively increased purinergic signaling in the lung.

Author Contributions: (1) Conception, design and data handling: (a) Substantial contributions to the conception and design of the manuscript: Djo Hasan, Toru Kotani, Gary F. Nieman; (b) Acquisition, analysis, or interpretation of data for the manuscript: Djo Hasan, Joshua Satalin, Philip van der Zee, Michaela Kollisch-Singule, Paul Blankman, Atsuko Shono, Peter Somhorst, Corstiaan den Uil, Han Meeder, Toru Kotani, Gary F. Nieman; (2) Drafting and revising the manuscript: (a) Drafting the manuscript: Djo Hasan, Joshua Satalin, Philip van der Zee, Gary F. Nieman; (b) Revising the manuscript critically for important intellectual content: Djo Hasan, Joshua Satalin, Philip van der Zee, Michaela Kollisch-Singule, PB, Atsuko Shono, Peter Somhorst, Corstiaan den Uil, Han Meeder, Toru Kotani, Gary F. Nieman; (3) Final approval of the version to be published: Djo Hasan, Joshua Satalin, Philip van der Zee, Michaela Kollisch-Singule, Paul Blankman, Atsuko Shono, Peter Somhorst, Corstiaan den Uil, Han Meeder, Toru Kotani, Gary F. Nieman; (4) Agreement to be accountable for all aspects of the work in ensuring that questions related to the accuracy or integrity of any part of the work are appropriately investigated and resolved: Djo Hasan, Joshua Satalin, Philip van der Zee, Michaela Kollisch-Singule, Paul Blankman, Atsuko Shono, Peter Somhorst, Corstiaan den Uil, Han Meeder, Toru Kotani, Gary F. Nieman.

Conflicts of Interest: Djo Hasan: The author reports to have received an honorarium to a lecture from Demcon-Macawi; Michaela Kollisch-Singule: The author reports to have received travel reimbursement at events sponsored by Dräger Medical; Gary F. Nieman.: The author reports to have received grants from the NIH, a grant from Dräger Medical, a grant from the CDRMP (DoD), travel and honorarium to lecture from Dräger Medical; Joshua Satalin, Philip van der Zee, Paul Blankman, Atsuko Shono, Peter Somhorst, Corstiaan den Uil, Han Meeder and Toru Kotani: The authors declare no conflicts of interest.

\section{References}

1. Lohmann, K. Über die Pyrophosphatfraktion im Muskel. Naturwissenschaften 1929, 17, 624-625. [CrossRef]

2. Langen, P.; Hucho, F. Karl Lohmann and the discovery of ATP. Angew. Chem. Int. Ed. Engl. 2008, 47, 1824-1827. [CrossRef] [PubMed]

3. Williams, R.J. The history and the hypotheses concerning ATP-formation by energised protons. FEBS Lett. 1978, 85, 9-19. [CrossRef]

4. Wikstrom, M.K.; Saari, H.T. Conformational changes in cytochrome aa3 and ATP synthetase of the mitochondrial membrane and their role in mitochondrial energy transduction. Mol. Cell. Biochem. 1976, 11, 17-33. [CrossRef] [PubMed]

5. Feldberg, W.; Hebb, C. The stimulating action of phosphate compounds on the perfused superior cervical ganglion of the cat. J. Physiol. 1948, 107, 210-221. [CrossRef] [PubMed] 
6. Holton, P. The liberation of adenosine triphosphate on antidromic stimulation of sensory nerves. J. Physiol. 1959, 145, 494-504. [CrossRef] [PubMed]

7. Burnstock, G. Purinergic nerves. Pharmacol. Rev. 1972, 24, 509-581. [PubMed]

8. Burnstock, G. Purinergic signalling: Its unpopular beginning, its acceptance and its exciting future. Bioessays 2012, 34, 218-225. [CrossRef] [PubMed]

9. Burnstock, G. Purinergic signalling: From discovery to current developments. Exp. Physiol. 2014, 99, $16-34$. [CrossRef] [PubMed]

10. Hasan, D.; Blankman, P.; Nieman, G.F. Purinergic signalling links mechanical breath profile and alveolar mechanics with the pro-inflammatory innate immune response causing ventilation-induced lung injury. Purinergic Signal. 2017, 13, 363-386. [CrossRef] [PubMed]

11. Gattinoni, L.; Tonetti, T.; Cressoni, M.; Cadringher, P.; Herrmann, P.; Moerer, O.; Protti, A.; Gotti, M.; Chiurazzi, C.; Carlesso, E.; et al. Ventilator-related causes of lung injury: The mechanical power. Intensive Care Med. 2016, 42, 1567-1575. [CrossRef] [PubMed]

12. Nieman, G.F.; Gatto, L.A.; Habashi, N.M. Impact of mechanical ventilation on the pathophysiology of progressive acute lung injury. J. Appl. Physiol. 2015, 119, 1245-1261. [CrossRef] [PubMed]

13. Slutsky, A.S.; Ranieri, V.M. Ventilator-induced lung injury. N. Engl. J. Med. 2013, 369, 2126-2136. [CrossRef] [PubMed]

14. Rezoagli, E.; Fumagalli, R.; Bellani, G. Definition and epidemiology of acute respiratory distress syndrome. Ann. Transl. Med. 2017, 5, 282. [CrossRef] [PubMed]

15. Cressoni, M.; Gotti, M.; Chiurazzi, C.; Massari, D.; Algieri, I.; Amini, M.; Cammaroto, A.; Brioni, M.; Montaruli, C.; Nikolla, K.; et al. Mechanical power and development of ventilator-induced lung injury. Anesthesiology 2016, 124, 1100-1108. [CrossRef] [PubMed]

16. Rich, P.B.; Douillet, C.D.; Mahler, S.A.; Husain, S.A.; Boucher, R.C. Adenosine triphosphate is released during injurious mechanical ventilation and contributes to lung edema. J. Trauma 2003, 55, 290-297. [CrossRef] [PubMed]

17. Matsuyama, H.; Amaya, F.; Hashimoto, S.; Ueno, H.; Beppu, S.; Mizuta, M.; Shime, N.; Ishizaka, A.; Hashimoto, S. Acute lung inflammation and ventilator-induced lung injury caused by ATP via the P2Y receptors: An experimental study. Respir. Res. 2008, 9, 79. [CrossRef] [PubMed]

18. Eltzschig, H.K.; Sitkovsky, M.V.; Robson, S.C. Purinergic signaling during inflammation. N. Engl. J. Med. 2012, 367, 2322-2333. [CrossRef] [PubMed]

19. Idzko, M.; Ferrari, D.; Eltzschig, H.K. Nucleotide signalling during inflammation. Nature 2014, 509, $310-317$. [CrossRef] [PubMed]

20. Cekic, C.; Linden, J. Purinergic regulation of the immune system. Nat. Rev. Immunol. 2016, 16, 177-192. [CrossRef] [PubMed]

21. Castro, C.Y. ARDS and diffuse alveolar damage: A pathologist's perspective. Semin. Thorac. Cardiovasc. Surg. 2006, 18, 13-19. [CrossRef] [PubMed]

22. Maruscak, A.A.; Vockeroth, D.W.; Girardi, B.; Sheikh, T.; Possmayer, F.; Lewis, J.F.; Veldhuizen, R.A. Alterations to surfactant precede physiological deterioration during high tidal volume ventilation. Am. J. Physiol. Lung Cell. Mol. Physiol. 2008, 294, L974-L983. [CrossRef] [PubMed]

23. Verbrugge, S.J.; Bohm, S.H.; Gommers, D.; Zimmerman, L.J.; Lachmann, B. Surfactant impairment after mechanical ventilation with large alveolar surface area changes and effects of positive end-expiratory pressure. Br. J. Anaesth. 1998, 80, 360-364. [CrossRef] [PubMed]

24. Martinez Sarrasague, M.; Cimato, A.; Rubin de Celis, E.; Facorro, G. Influence of serum protein and albumin addition on the structure and activity of an exogenous pulmonary surfactant. Respir. Physiol. Neurobiol. 2011, 175, 316-321. [CrossRef] [PubMed]

25. Faridy, E.E. Effect of ventilation on movement of surfactant in airways. Respir. Physiol. 1976, $27,323-334$. [CrossRef]

26. Pettenazzo, A.; Jobe, A.; Humme, J.; Seidner, S.; Ikegami, M. Clearance of surfactant phosphatidylcholine via the upper airways in rabbits. J. Appl. Physiol. 1988, 65, 2151-2155. [CrossRef] [PubMed]

27. Martinez, F.; Lewis, J.; Copland, I.; Engelberts, D.; Kavanagh, B.P.; Post, M.; Schurch, S.; Belik, J. Mechanical ventilation effect on surfactant content, function, and lung compliance in the newborn rat. Pediatr. Res. 2004, 56, 19-25. [CrossRef] [PubMed] 
28. Cressoni, M.; Chiurazzi, C.; Gotti, M.; Amini, M.; Brioni, M.; Algieri, I.; Cammaroto, A.; Rovati, C.; Massari, D.; di Castiglione, C.B.; et al. Lung inhomogeneities and time course of ventilator-induced mechanical injuries. Anesthesiology 2015, 123, 618-627. [CrossRef] [PubMed]

29. Petersen, B.; Busch, T.; Gaertner, J.; Haitsma, J.J.; Krabbendam, S.; Ebsen, M.; Lachmann, B.; Kaisers, U.X. Complement activation contributes to ventilator-induced lung injury in rats. J. Physiol. Pharmacol. 2016, 67, 911-918. [PubMed]

30. Schwiebert, E.M.; Zsembery, A. Extracellular ATP as a signaling molecule for epithelial cells. Biochim. Biophys. Acta 2003, 1615, 7-32. [CrossRef]

31. Lazarowski, E.R.; Boucher, R.C.; Harden, T.K. Constitutive release of ATP and evidence for major contribution of ecto-nucleotide pyrophosphatase and nucleoside diphosphokinase to extracellular nucleotide concentrations. J. Biol. Chem. 2000, 275, 31061-31068. [CrossRef] [PubMed]

32. Patel, A.S.; Reigada, D.; Mitchell, C.H.; Bates, S.R.; Margulies, S.S.; Koval, M. Paracrine stimulation of surfactant secretion by extracellular ATP in response to mechanical deformation. Am. J. Physiol. Lung Cell. Mol. Physiol. 2005, 289, L489-L496. [CrossRef] [PubMed]

33. Furuya, K.; Tan, J.J.; Boudreault, F.; Sokabe, M.; Berthiaume, Y.; Grygorczyk, R. Real-time imaging of inflation-induced ATP release in the ex-vivo rat lung. Am. J. Physiol. Lung Cell. Mol. Physiol. 2016, 311, L956-L969. [CrossRef] [PubMed]

34. Brandao-Burch, A.; Key, M.L.; Patel, J.J.; Arnett, T.R.; Orriss, I.R. The P2X7 Receptor is an Important Regulator of Extracellular ATP Levels. Front. Endocrinol. 2012, 3, 41. [CrossRef] [PubMed]

35. Mishra, A.; Chintagari, N.R.; Guo, Y.; Weng, T.; Su, L.; Liu, L. Purinergic P2X7 receptor regulates lung surfactant secretion in a paracrine manner. J. Cell Sci. 2011, 124, 657-668. [CrossRef] [PubMed]

36. Brunschweiger, A.; Muller, C.E. P2 receptors activated by uracil nucleotides-An update. Curr. Med. Chem. 2006, 13, 289-312. [CrossRef] [PubMed]

37. Wettschureck, N.; Offermanns, S. Mammalian G proteins and their cell type specific functions. Physiol. Rev. 2005, 85, 1159-1204. [CrossRef] [PubMed]

38. Berridge, M.J. Inositol trisphosphate and diacylglycerol: Two interacting second messengers. Annu. Rev. Biochem. 1987, 56, 159-193. [CrossRef] [PubMed]

39. Hogan, P.G.; Rao, A. Store-operated calcium entry: Mechanisms and modulation. Biochem. Biophys. Res. Commun. 2015, 460, 40-49. [CrossRef] [PubMed]

40. Lanner, J.T.; Georgiou, D.K.; Joshi, A.D.; Hamilton, S.L. Ryanodine receptors: Structure, expression, molecular details, and function in calcium release. Cold Spring Harb. Perspect. Biol. 2010, 2, a003996. [CrossRef] [PubMed]

41. O'Neil, R.G.; Heller, S. The mechanosensitive nature of TRPV channels. Pflügers Arch. 2005, 451, $193-203$. [CrossRef] [PubMed]

42. Keselman, I.; Fribourg, M.; Felsenfeld, D.P.; Logothetis, D.E. Mechanism of PLC-mediated Kir3 current inhibition. Channels 2007, 1, 113-123. [CrossRef] [PubMed]

43. Clarke, L.L.; Harline, M.C.; Otero, M.A.; Glover, G.G.; Garrad, R.C.; Krugh, B.; Walker, N.M.; Gonzalez, F.A.; Turner, J.T.; Weisman, G.A. Desensitization of P2Y2 receptor-activated transepithelial anion secretion. Am. J. Physiol. 1999, 276, C777-C787. [CrossRef] [PubMed]

44. Varela, D.; Penna, A.; Simon, F.; Eguiguren, A.L.; Leiva-Salcedo, E.; Cerda, O.; Sala, F.; Stutzin, A. P2X4 activation modulates volume-sensitive outwardly rectifying chloride channels in rat hepatoma cells. J. Biol. Chem. 2010, 285, 7566-7574. [CrossRef] [PubMed]

45. Rasmussen, H.; Isales, C.M.; Calle, R.; Throckmorton, D.; Anderson, M.; Gasalla-Herraiz, J.; McCarthy, R. Diacylglycerol production, $\mathrm{Ca}^{2+}$ influx, and protein kinase $\mathrm{C}$ activation in sustained cellular responses. Endocr. Rev. 1995, 16, 649-681. [CrossRef] [PubMed]

46. Dietl, P.; Haller, T.; Frick, M. Spatio-temporal aspects, pathways and actions of $\mathrm{Ca}^{2+}$ in surfactant secreting pulmonary alveolar type II pneumocytes. Cell Calcium 2012, 52, 296-302. [CrossRef] [PubMed]

47. Miklavc, P.; Mair, N.; Wittekindt, O.H.; Haller, T.; Dietl, P.; Felder, E.; Timmler, M.; Frick, M. Fusion-activated $\mathrm{Ca}^{2+}$ entry via vesicular P2X4 receptors promotes fusion pore opening and exocytotic content release in pneumocytes. Proc. Natl. Acad. Sci. USA 2011, 108, 14503-14508. [CrossRef] [PubMed]

48. Thompson, K.E.; Korbmacher, J.P.; Hecht, E.; Hobi, N.; Wittekindt, O.H.; Dietl, P.; Kranz, C.; Frick, M. Fusion-activated cation entry (FACE) via P2X4 couples surfactant secretion and alveolar fluid transport. FASEB J. 2013, 27, 1772-1783. [CrossRef] [PubMed] 
49. Fois, G.; Winkelmann, V.E.; Bareis, L.; Staudenmaier, L.; Hecht, E.; Ziller, C.; Ehinger, K.; Schymeinsky, J.; Kranz, C.; Frick, M. ATP is stored in lamellar bodies to activate vesicular P2X4 in an autocrine fashion upon exocytosis. J. Gen. Physiol. 2018, 150, 277-291. [CrossRef] [PubMed]

50. Moriyama, Y.; Hiasa, M.; Sakamoto, S.; Omote, H.; Nomura, M. Vesicular nucleotide transporter (VNUT): Appearance of an actress on the stage of purinergic signaling. Purinergic Signal. 2017, 13, 387-404. [CrossRef] [PubMed]

51. Zhong, X.Z.; Cao, Q.; Sun, X.; Dong, X.P. Activation of lysosomal P2X4 by ATP transported into lysosomes via VNUT/SLC17A9 using V-ATPase generated voltage gradient as the driving force. J. Physiol. 2016, 594, 4253-4266. [CrossRef] [PubMed]

52. Stojilkovic, S.S.; Yan, Z.; Obsil, T.; Zemkova, H. Structural insights into the function of P2X4: An ATP-gated cation channel of neuroendocrine cells. Cell. Mol. Neurobiol. 2010, 30, 1251-1258. [CrossRef] [PubMed]

53. Zemkova, H.; Khadra, A.; Rokic, M.B.; Tvrdonova, V.; Sherman, A.; Stojilkovic, S.S. Allosteric regulation of the P2X4 receptor channel pore dilation. Pflügers Arch. 2015, 467, 713-726. [CrossRef] [PubMed]

54. Lock, J.T.; Parker, I.; Smith, I.F. Communication of $\mathrm{Ca}^{2+}$ signals via tunneling membrane nanotubes is mediated by transmission of inositol trisphosphate through gap junctions. Cell Calcium 2016, 60, 266-272. [CrossRef] [PubMed]

55. Rustom, A.; Saffrich, R.; Markovic, I.; Walther, P.; Gerdes, H.-H. Nanotubular highways for intercellular organelle transport. Science 2004, 303, 1007-1010. [CrossRef] [PubMed]

56. Koval, M. Sharing signals: Connecting lung epithelial cells with gap junction channels. Am. J. Physiol. Lung Cell. Mol. Physiol. 2002, 283, L875-L893. [CrossRef] [PubMed]

57. Miklavc, P.; Wittekindt, O.H.; Felder, E.; Dietl, P. Ca ${ }^{2+}$-dependent actin coating of lamellar bodies after exocytotic fusion: A prerequisite for content release or kiss-and-run. Ann. N. Y. Acad. Sci. 2009, 1152, 43-52. [CrossRef] [PubMed]

58. Haller, T.; Dietl, P.; Pfaller, K.; Frick, M.; Mair, N.; Paulmichl, M.; Hess, M.W.; Furst, J.; Maly, K. Fusion pore expansion is a slow, discontinuous, and $\mathrm{Ca}^{2+}$-dependent process regulating secretion from alveolar type II cells. J. Cell Biol. 2001, 155, 279-289. [CrossRef] [PubMed]

59. Strayer, D.S.; Yang, S.; Jerng, H.H. Surfactant protein A-binding proteins. Characterization and structures. J. Biol. Chem. 1993, 268, 18679-18684. [PubMed]

60. Wissel, H.; Looman, A.C.; Fritzsche, I.; Rustow, B.; Stevens, P.A. SP-A-binding protein BP55 is involved in surfactant endocytosis by type II pneumocytes. Am. J. Physiol. 1996, 271, L432-L440. [CrossRef] [PubMed]

61. Kresch, M.J.; Christian, C.; Lu, H. Isolation and partial characterization of a receptor to surfactant protein A expressed by rat type II pneumocytes. Am. J. Respir. Cell Mol. Biol. 1998, 19, 216-225. [CrossRef] [PubMed]

62. Chroneos, Z.C.; Abdolrasulnia, R.; Whitsett, J.A.; Rice, W.R.; Shepherd, V.L. Purification of a cell-surface receptor for surfactant protein A. J. Biol. Chem. 1996, 271, 16375-16383. [CrossRef] [PubMed]

63. Fukuzawa, T.; Ishida, J.; Kato, A.; Ichinose, T.; Ariestanti, D.M.; Takahashi, T.; Ito, K.; Abe, J.; Suzuki, T.; Wakana, S.; et al. Lung surfactant levels are regulated by Ig-Hepta/GPR116 by monitoring surfactant protein D. PLoS ONE 2013, 8, e69451. [CrossRef] [PubMed]

64. Cooley, J.; McDonald, B.; Accurso, F.J.; Crouch, E.C.; Remold-O'Donnell, E. Patterns of neutrophil serine protease-dependent cleavage of surfactant protein D in inflammatory lung disease. J. Leukoc. Biol. 2008, 83, 946-955. [CrossRef] [PubMed]

65. Rubio, F.; Cooley, J.; Accurso, F.J.; Remold-O'Donnell, E. Linkage of neutrophil serine proteases and decreased surfactant protein-A (SP-A) levels in inflammatory lung disease. Thorax 2004, 59, 318-323. [CrossRef] [PubMed]

66. Belete, H.A.; Hubmayr, R.D.; Wang, S.; Singh, R.D. The role of purinergic signaling on deformation induced injury and repair responses of alveolar epithelial cells. PLoS ONE 2011, 6, e27469. [CrossRef] [PubMed]

67. Bates, S.R. P63 (CKAP4) as an SP-A receptor: Implications for surfactant turnover. Cell. Physiol. Biochem. 2010, 25, 41-54. [CrossRef] [PubMed]

68. Ren, H.; Birch, N.P.; Suresh, V. An Optimised Human Cell Culture Model for Alveolar Epithelial Transport. PLoS ONE 2016, 11, e0165225. [CrossRef] [PubMed]

69. Olmeda, B.; Martinez-Calle, M.; Perez-Gil, J. Pulmonary surfactant metabolism in the alveolar airspace: Biogenesis, extracellular conversions, recycling. Ann. Anat. 2017, 209, 78-92. [CrossRef] [PubMed] 
70. Zuo, Y.Y.; Veldhuizen, R.A.; Neumann, A.W.; Petersen, N.O.; Possmayer, F. Current perspectives in pulmonary surfactant-Inhibition, enhancement and evaluation. Biochim. Biophys. Acta 2008, 1778, 1947-1977. [CrossRef] [PubMed]

71. Parra, E.; Perez-Gil, J. Composition, structure and mechanical properties define performance of pulmonary surfactant membranes and films. Chem. Phys. Lipids 2015, 185, 153-175. [CrossRef] [PubMed]

72. Olmeda, B.; Villen, L.; Cruz, A.; Orellana, G.; Perez-Gil, J. Pulmonary surfactant layers accelerate O2 diffusion through the air-water interface. Biochim. Biophys. Acta 2010, 1798, 1281-1284. [CrossRef] [PubMed]

73. Baoukina, S.; Tieleman, D.P. Computer simulations of lung surfactant. Biochim. Biophys. Acta 2016, 1858, 2431-2440. [CrossRef] [PubMed]

74. Sibug-Aga, R.; Dunn, R.C. High-resolution studies of lung surfactant collapse. Photochem. Photobiol. 2004, 80, 471-476. [CrossRef]

75. Schief, W.R.; Antia, M.; Discher, B.M.; Hall, S.B.; Vogel, V. Liquid-crystalline collapse of pulmonary surfactant monolayers. Biophys. J. 2003, 84, 3792-3806. [CrossRef]

76. Mokra, D.; Kosutova, P. Biomarkers in acute lung injury. Respir. Physiol. Neurobiol. 2015, 209, 52-58. [CrossRef] [PubMed]

77. Demberg, L.M.; Winkler, J.; Wilde, C.; Simon, K.U.; Schon, J.; Rothemund, S.; Schoneberg, T.; Promel, S.; Liebscher, I. Activation of Adhesion G Protein-coupled Receptors: Agonist specificity of Stachel sequence-derived peptides. J. Biol. Chem. 2017, 292, 4383-4394. [CrossRef] [PubMed]

78. Burk, S.E.; Lytton, J.; MacLennan, D.H.; Shull, G.E. cDNA cloning, functional expression, and mRNA tissue distribution of a third organellar $\mathrm{Ca}^{2+}$ pump. J. Biol. Chem. 1989, 264, 18561-18568. [PubMed]

79. Allen, B.G.; Katz, S. Phosphorylation of cardiac junctional and free sarcoplasmic reticulum by PKC $\alpha$, PKC beta, PKA and the $\mathrm{Ca}^{2+} /$ calmodulin-dependent protein kinase. Mol. Cell. Biochem. 1996, 155, 91-103. [CrossRef] [PubMed]

80. Caride, A.J.; Filoteo, A.G.; Enyedi, A.; Verma, A.K.; Penniston, J.T. Detection of isoform 4 of the plasma membrane calcium pump in human tissues by using isoform-specific monoclonal antibodies. Biochem. J. 1996, 316 (Pt 1), 353-359. [CrossRef] [PubMed]

81. Dong, X.; Thomas, D.D. Time-resolved FRET reveals the structural mechanism of SERCA-PLB regulation. Biochem. Biophys. Res. Commun. 2014, 449, 196-201. [CrossRef] [PubMed]

82. Ritchie, M.F.; Samakai, E.; Soboloff, J. STIM1 is required for attenuation of PMCA-mediated Ca ${ }^{2+}$ clearance during T-cell activation. EMBO J. 2012, 31, 1123-1133. [CrossRef] [PubMed]

83. Garrad, R.C.; Otero, M.A.; Erb, L.; Theiss, P.M.; Clarke, L.L.; Gonzalez, F.A.; Turner, J.T.; Weisman, G.A. Structural basis of agonist-induced desensitization and sequestration of the P2Y2 nucleotide receptor. Consequences of truncation of the C terminus. J. Biol. Chem. 1998, 273, 29437-29444. [CrossRef] [PubMed]

84. Flores, R.V.; Hernandez-Perez, M.G.; Aquino, E.; Garrad, R.C.; Weisman, G.A.; Gonzalez, F.A. Agonist-induced phosphorylation and desensitization of the P2Y2 nucleotide receptor. Mol. Cell. Biochem. 2005, 280, 35-45. [CrossRef] [PubMed]

85. Gutierrez, A.M.; Lou, X.; Erik, A.; Persson, G.; Ring, A. Growth hormones reverse desensitization of P2Y2 receptors in rat mesangial cells. Biochem. Biophys. Res. Commun. 2000, 270, 594-599. [CrossRef] [PubMed]

86. Sromek, S.M.; Harden, T.K. Agonist-induced internalization of the P2Y2 receptor. Mol. Pharmacol. 1998, 54, 485-494. [CrossRef] [PubMed]

87. Stokes, L. Rab5 regulates internalisation of P2X4 receptors and potentiation by ivermectin. Purinergic Signal. 2013, 9, 113-121. [CrossRef] [PubMed]

88. Eckle, T.; Fullbier, L.; Wehrmann, M.; Khoury, J.; Mittelbronn, M.; Ibla, J.; Rosenberger, P.; Eltzschig, H.K. Identification of ectonucleotidases CD39 and CD73 in innate protection during acute lung injury. J. Immunol. 2007, 178, 8127-8137. [CrossRef] [PubMed]

89. Surprenant, A.; Rassendren, F.; Kawashima, E.; North, R.A.; Buell, G. The cytolytic P2Z receptor for extracellular ATP identified as a P2X receptor (P2X7). Science 1996, 272, 735-738. [CrossRef] [PubMed]

90. Vaneker, M.; Halbertsma, F.J.; van Egmond, J.; Netea, M.G.; Dijkman, H.B.; Snijdelaar, D.G.; Joosten, L.A.; van der Hoeven, J.G.; Scheffer, G.J. Mechanical ventilation in healthy mice induces reversible pulmonary and systemic cytokine elevation with preserved alveolar integrity: An in vivo model using clinical relevant ventilation settings. Anesthesiology 2007, 107, 419-426. [CrossRef] [PubMed] 
91. Morad, H.O.; Belete, S.C.; Read, T.; Shaw, A.M. Time-course analysis of C3a and C5a quantifies the coupling between the upper and terminal Complement pathways in vitro. J. Immunol. Methods 2015, 427, 13-18. [CrossRef] [PubMed]

92. Williams, T.J. Vascular permeability changes induced by complement-derived peptides. Agents Act. 1983, 13, 451-455. [CrossRef] [PubMed]

93. Wittekindt, O.H. Tight junctions in pulmonary epithelia during lung inflammation. Pflügers Arch. 2017, 469, 135-147. [CrossRef] [PubMed]

94. Barth, K.; Blasche, R.; Neisser, A.; Bramke, S.; Frank, J.A.; Kasper, M. P2X7R-dependent regulation of glycogen synthase kinase $3 \beta$ and claudin-18 in alveolar epithelial type I cells of mice lung. Histochem. Cell Biol. 2016, 146, 757-768. [CrossRef] [PubMed]

95. Wray, C.; Mao, Y.; Pan, J.; Chandrasena, A.; Piasta, F.; Frank, J.A. Claudin-4 augments alveolar epithelial barrier function and is induced in acute lung injury. Am. J. Physiol. Lung Cell. Mol. Physiol. 2009, 297, L219-L227. [CrossRef] [PubMed]

96. Yang, F.; Zhao, K.; Zhang, X.; Zhang, J.; Xu, B. ATP induces disruption of tight junction proteins via IL-1 $\beta$-dependent MMP-9 activation of human blood-brain barrier in vitro. Neural Plast. 2016, 2016, 8928530. [CrossRef] [PubMed]

97. Sera, T.; Yokota, H.; Tanaka, G.; Uesugi, K.; Yagi, N.; Schroter, R.C. Murine pulmonary acinar mechanics during quasi-static inflation using synchrotron refraction-enhanced computed tomography. J. Appl. Physiol. 2013, 115, 219-228. [CrossRef] [PubMed]

98. Albert, S.P.; DiRocco, J.; Allen, G.B.; Bates, J.H.; Lafollette, R.; Kubiak, B.D.; Fischer, J.; Maroney, S.; Nieman, G.F. The role of time and pressure on alveolar recruitment. J. Appl. Physiol. 2009, 106, 757-765. [CrossRef] [PubMed]

99. Suki, B.; Bates, J.H. Lung tissue mechanics as an emergent phenomenon. J. Appl. Physiol. 2011, 110, 1111-1118. [CrossRef] [PubMed]

100. Kollisch-Singule, M.; Emr, B.; Smith, B.; Ruiz, C.; Roy, S.; Meng, Q.; Jain, S.; Satalin, J.; Snyder, K.; Ghosh, A.; et al. Airway pressure release ventilation reduces conducting airway micro-strain in lung injury. J. Am. Coll. Surg. 2014, 219, 968-976. [CrossRef] [PubMed]

101. Ochs, M.; Nyengaard, J.R.; Jung, A.; Knudsen, L.; Voigt, M.; Wahlers, T.; Richter, J.; Gundersen, H.J. The number of alveoli in the human lung. Am. J. Respir. Crit. Care Med. 2004, 169, 120-124. [CrossRef] [PubMed]

102. Barre, S.F.; Haberthur, D.; Stampanoni, M.; Schittny, J.C. Efficient estimation of the total number of acini in adult rat lung. Physiol. Rep. 2014, 2, e12063. [CrossRef] [PubMed]

103. Satalin, J.; Jain, S.V.; Kollisch-Singule, M.C.; Andrews, P.L.; Searles, Q.; Sweeney, T.; Gatto, L.A.; Habashi, N.M.; Nieman, G.F. Discerning expiratory time vs. pressure in preventing in-vivo alveolar collapse. Respir. Care 2016, 61, OF41.

104. Roy, S.; Habashi, N.; Sadowitz, B.; Andrews, P.; Ge, L.; Wang, G.; Roy, P.; Ghosh, A.; Kuhn, M.; Satalin, J.; et al. Early airway pressure release ventilation prevents ARDS-A novel preventive approach to lung injury. Shock 2013, 39, 28-38. [CrossRef] [PubMed]

105. Silva, P.L.; Cruz, F.F.; Samary, C.D.S.; Moraes, L.; de Magalhaes, R.F.; Fernandes, M.V.S.; Bose, R.; Pelegati, V.B.; Carvalho, H.F.; Capelozzi, V.L.; et al. Biological response to time-controlled adaptive ventilation depends on acute respiratory distress syndrome etiology. Crit. Care Med. 2018. [CrossRef] [PubMed]

106. Bellingan, G.; Maksimow, M.; Howell, D.C.; Stotz, M.; Beale, R.; Beatty, M.; Walsh, T.; Binning, A.; Davidson, A.; Kuper, M.; et al. The effect of intravenous interferon- $\beta$-1a (FP-1201) on lung CD73 expression and on acute respiratory distress syndrome mortality: An open-label study. Lancet Respir. Med. 2014, 2, 98-107. [CrossRef]

107. Cavalcanti, A.B.; Suzumura, E.A.; Laranjeira, L.N.; Paisani, D.M.; Damiani, L.P.; Guimaraes, H.P.; Romano, E.R.; Regenga, M.M.; Taniguchi, L.N.T.; Teixeira, C.; et al. Effect of lung recruitment and titrated positive end-expiratory pressure (PEEP) vs low PEEP on mortality in patients with acute respiratory distress syndrome: A randomized clinical trial. JAMA 2017, 318, 1335-1345. [CrossRef] [PubMed]

(C) 2018 by the authors. Licensee MDPI, Basel, Switzerland. This article is an open access article distributed under the terms and conditions of the Creative Commons Attribution (CC BY) license (http:/ / creativecommons.org/licenses/by/4.0/). 